\title{
Technical Review of The Role Physical Conditions in Football
}

\section{Awang Firmansyaha*, Reza Aziz Prasetya ${ }^{\text {b }}$, Muchamad Arif Al Ardha ${ }^{c}$}

abcUniversitas Negeri Surabaya, Indonesia

'National Dong Hwa University, Taiwan

Correspondence: awangfirmansyah@unesa.ac.id

Received: 24 Mar 2021 Accepted: 29 Apr 2021 Published: 30 Apr 2021

\begin{abstract}
Football requires good physical condition in playing and competing. There are four phases in football training, namely physical, technical, tactical and mental. This study discusses the physical conditions required in the sport of football and was analyzed using the review method against references published online, related to physical conditions. In this research, it shows that the physical components in football are very influential in the game. The components of the physical conditions developed in the need to support the game of football are very broad. Research related to physical components is carried out for various techniques in football. However, the trend of physical components that is commonly used is the physical component in general such as strength, flexibility, speed, endurance and anthropometric conditions, namely arm length, leg length.
\end{abstract}

Keywords: role; physical condition; football.

\section{Introduction}

Sports as one of the elements in human life, if empowered through various appropriate ways, is an effort to rise up. In order to form character, discipline, competitive advantage, productivity and useful work ethic of individuals doing it in a sporting manner, sport becomes important in improving the quality of human resources for the desired achievement (Fauzi, 2013).

Sport is an activity that is needed by everyone to maintain their health and physical fitness. The sports are physical activities that support health, thhis is in accordance with what was expressed by (Anwar, Pendidikan, Kesehatan, \& Keolahragaan, 2013). In addition to providing physical health and fitness, sports activities can be used as a means of competence to race in achieving an achievement, both individually and in groups (Azidman, 2017).

Football is a sport that is very popular in the world and this sport is very easy to understand and the attractiveness of football lies in the naturalness of the game and is a dynamic sport that requires excellent physical condition for football players, because in the game football is required to run at all times to chase, dribble, grab the ball from the opponent, move in all directions quickly, move the feet and hands and head appropriately, and jump precisely (Stoica \& Blejan, 2013). In playing football, of course, it requires good physical condition (Haxhiu, Gara, Durguti, \& Gashi, 2016). Physical condition is an important element and becomes the basis for developing techniques, tactics, and strategies in playing football (Thompsett, Harland, \& Roberts, 2016). The role of physical conditions as a foundation in every activity we carry out in training (Roberts et al., 2020).

The physical needs of a football player should include flexibility training, repetitive sprint training to improve anaerobic ability, continuous running training sessions to improve cardiac capacity, and 
strength training to develop muscle and bone systems. Physical development aspects that need to be considered by players such as diet, adequate rest and regular training so that players can maintain their physical fitness, a player must be in good physical condition because in sports football requires good stamina and requires movements such as running, changing direction and strong endurance.

Exercise needs to be applied with due regard to the age factor because exercise patterns that exceed the dose of muscle ability will affect a person's physical development. The physical abilities of football athletes play a very important role in the training activity program. In order to achieve maximum peak performance results. Physical abilities are aimed at improving physical fitness and functional abilities of the body systems, thereby enabling footballers to achieve better performance in competition (PérezGómez, Adsuar, Alcaraz, \& Carlos-Vivas, 2020). So that this review will describe the components of the physical condition that must be developed by the coaches (Utama, Insanistyo, \& Syafrial, 2017).

\section{Method}

The preparation of this article was carried out by analysis using the review method (Guntoro et al., 2010) and (Mislan \& Santoso, 2019). Reviews are carried out on references related to the results of research on learning media, especially on components of physical conditions. References are obtained from research results and supporting articles published online such as in Sciencedirect, Pubmed, Journal of Physical Education, British Journal of Sport Medicine and local journal in Indonesia. The analysis was carried out by grouping the research results into the components of the physical condition. The grouping is shown in the form of a table showing the types of physical components studied and the success rate of the physical components studied in the sport of football. The results of the grouping are then analyzed according to the existing trends. This is done to keep the writing up to date based on the latest research results.

\section{Result}

The sport of football has defining aspects, just like sports in general. Football is a complex game that requires specific practice. Football players must have good aerobic fitness, speed, strength, soccer skills, understand basic tactics and strategies for playing football (Thompsett et al., 2016).

Physical development aspects that need to be considered by players such as diet, adequate rest and regular training so that players can maintain their physical fitness. A player must have a good physical condition because in the sport, football requires good stamina and requires movements such as running, changing direction and strong endurance (Anam, 2013). Basically the components of the physical condition in the sport of football are very important, but necessary An analysis of the character of the components of the physical condition is very dominant in soccer games. Given that not all components of the physical condition are owned by every football player.

Based on the above understanding, the role of physical conditions in providing information and motivating athletes to continue to improve their physical condition abilities, so that training objectives can be achieved properly. However, the selection and use of physical condition components must also be adapted to the characteristics of the football game. The game of football really requires excellent physical condition. The variety of physical conditions with the characteristics and needs in the game causes the use of relatively different training models. Physical conditions are preferred for the need for direct implementation or practice in football games. Here are some examples of research on the components of physical conditions in the sport of football. 
Table 1. Examples of Research on the Components of Physical Conditions in Football

\begin{tabular}{|c|c|c|}
\hline Types of Physical Conditions & Application Results & Reference \\
\hline Speed and flexibility & $\begin{array}{l}\text { There is a significant contribution } \\
\text { between speed and flexibility to the } \\
\text { results of dribbling in football games. }\end{array}$ & (Pratama, 2015) \\
\hline Flexibility and explosive power & $\begin{array}{l}\text { Good headings, athletes must have } \\
\text { good waist flexibility and leg muscle } \\
\text { explosive power in order to be able to } \\
\text { do headings optimally }\end{array}$ & (Putra \& S, 2020) \\
\hline Strength, leg length and balance & $\begin{array}{l}\text { There is a significant contribution } \\
\text { between leg muscle strength, leg } \\
\text { length, and balance to the ability to } \\
\text { kick a ball. }\end{array}$ & $\begin{array}{l}\text { ((Maulana et al., } \\
\text { 2019) }\end{array}$ \\
\hline Speed, agility and coordination & $\begin{array}{l}\text { There is a significant contribution of } \\
\text { speed, agility, and eye coordination to } \\
\text { the ability to dribble in football }\end{array}$ & (Adil, 2011) \\
\hline Waist flexibility and agility & $\begin{array}{l}\text { Waist flexibility and agility have a } \\
\text { significant and empirically accepted } \\
\text { relationship and dribbling ability in } \\
\text { football athletes. }\end{array}$ & (Putra, 2020) \\
\hline $\begin{array}{l}\text { Calf length, thigh length, and leg } \\
\text { explosive power }\end{array}$ & $\begin{array}{l}\text { There is a significant contribution } \\
\text { between the anthropometric length of } \\
\text { the calf, the length of the thigh, and the } \\
\text { explosive power of the leg, kicking } \\
\text { accuracy. }\end{array}$ & $\begin{array}{l}\text { Yusuf Ditya, } \\
\text { 2013) }\end{array}$ \\
\hline Cardiovascular endurance & $\begin{array}{l}\text { There is a positive relationship } \\
\text { between cardiovascular endurance and } \\
\text { the ability to play football. }\end{array}$ & (Yulinar, 2018 ) \\
\hline $\begin{array}{l}\text { Maximum Oxygen Volume } \\
\left(\mathrm{VO}_{2} \max \right) \text { and Muscle Endurance }\end{array}$ & $\begin{array}{l}\text { There is a relationship between the } \\
\text { value of maximum oxygen volume } \\
\left(\mathrm{VO}_{2} \mathrm{max}\right) \text { and muscle endurance in } \\
\text { football players. }\end{array}$ & (Hamid, 2019) \\
\hline $\begin{array}{l}\text { Lung Vital Capacity With } \\
\text { Cardiorespiratory Endurance }\end{array}$ & $\begin{array}{l}\text { The results of this study indicate a } \\
\text { relationship between vital lung capacity } \\
\text { and cardiorespiratory endurance by } \\
22.7 \% \text { and the remaining } 77.3 \% \text { is } \\
\text { influenced by other factors. }\end{array}$ & $\begin{array}{l}\text { (Syahda, } \\
\text { Damayanti, \& } \\
\text { Imanudin, 2016) }\end{array}$ \\
\hline Physical ability & $\begin{array}{l}\text { The most dominant factor influencing } \\
\text { football skill is speed, while the lowest } \\
\text { is endurance. }\end{array}$ & $\begin{array}{l}\text { (Guntoro, } \\
\text { Muhammad, \& } \\
\text { Qomarrullah, } \\
\text { 2020) }\end{array}$ \\
\hline
\end{tabular}

Based on table 1 above, it shows that the components of physical conditions have been widely studied for football games such as flexibility, speed, agility, endurance, anthropometry, muscle endurance, 
$\mathrm{VO}_{2} \mathrm{Max}$, and cardiorespiratory endurance. This means that the role of physical condition components in the sport of football is very much needed.

\section{Discussion}

Speed is a fundamental physical component, so speed is a determining factor in sports such as short distance running numbers, swimming, self-defense and game sports and the ability to perform similar movements consecutively in the shortest time. Clasically, sprinting speed is described to be the product of stride frequency and stride length (Gamble, 2012). In short or the ability to cover the shortest distance in this case if the player moves by using the fast muscle abilities in the leg, then the movement of the leg will be done quickly. So that it can support the ability to dribble in the game of football, speed is needed to make similar movements in succession in the shortest possible time. Because in the process the movement can only be done briefly, it requires the ability of physical conditions that can support speed. Factors that affect a person's speed, power, muscle viscosity, reaction speed, contraction speed, coordination between the central nerve and muscles, anthropometric characteristics, and power hold up, speed. Based on the motion of speed and its application in sports activities, the element of speed is an important element in achieving optimal results. The implication of velocity is in the form of partial reaction speed, while movement speed is the key of the limbs as a whole in covering a certain distance such as running. Flexibility is related to the presence of wider joint space and muscle elasticity. Flexibility can be defined as the ability to move joints and muscles throughout their space. Apart from joints, flexibility is also determined by the elasticity of the tendons and ligaments. Flexibility can be obtained through a variety of stretching exercises that can be done anywhere and in any position. Flexibility is characterized by the extent of movement that can be performed at the joint.

The explosive power of the leg muscles is one component of an indispensable physical condition. Without having good leg muscle explosive power, the results will not be optimal. Power is combination between speed and strength (Bompa \& Buzzichelli, 2015). In principle, leg muscle strength is the muscle's ability to generate tension against a resistance. If the athlete have sufficient leg muscle strength it can be correlate to kick a ball in a football game, it will certainly contribute to providing optimal results. If the leg muscle strength is considered, then physiologically it will result in a better ability to kick a ball in football. Leg muscle strength is a precondition that supports various sports including football, especially the ability to kick a ball. Therefore, good leg muscle strength really supports the achievement of optimal football kicking ability.

Agility is a physical component that is widely used in sports. Agility is generally defined as the ability to change direction effectively and quickly, while running almost fully. Agility is the skill and abilities needed to change of direction, velocity, or mode in response to a stimulus (Haff \& Triplett, 2016). Agility occurs because of the explosive power movement. The amount of energy is determined by the strength of the contraction of muscle fibers. Muscle speed depends on the strength and contraction of muscle fibers. The rate of muscle contraction depends on the adhesiveness of the muscle fibers and the speed of transmission of nerve impulses, both of which are innate or genetic, athletes cannot change them. In the sport of football, to produce good agility that can facilitate the mastery of effective and efficient playing techniques in providing energy, one of which can be done with zigzag running training. Zigzag running practice can facilitate environmental orientation and teammate movements and play movements. Maneuvering with the ball or dribbling the zigzagging ball past the opponent cannot be done slowly but with sudden and rapid movements in changing direction. If an athlete can dribble the ball well, it can help his movement, so that the opponent is difficult to read the direction of movement and difficulty in grabbing the ball. On the other hand, if an athlete is unable to dribble the ball well, the ball movement will be easy to predict in direction so that the opponent will easily snatch the ball. 
Anthropometry is a study that is concerned with measuring the dimensions of the human body. The field of anthropometry includes various measurements of the human body such as body weight, position when standing, when stretching arms, body circumference, leg length, and so on. There is a significant contribution between the variable calf length anthropometry, thigh length anthropometry and leg explosive power to kicking accuracy. Anthropometric data is used for various purposes, such as designing work stations, work facilities, product design in order to obtain appropriate equipment in sport and proper sizes with the dimensions of the human limbs that will use them.

Endurance is the ability of a person to carry out movements with his entire body for a long time and with a moderate to fast tempo without excessive fatigue. Aerobic Endurance training results in reduced body fat, increased maximal oxygen uptake, increased running economy, increased respiratory capacity, lower blood lactate concentration at submaximal exercise, increase mitochondrial and capillary densities and improved enzyme activity (Haff \& Triplett, 2016). Football is a game that requires a high level of endurance and requires adequate oxygen at the time. Metabolic responses and their relationship to recreational football were displayed through changes in blood lipids, glucose concentration and gucose tolerance (Milanović et al., 2019). The quality of one's game really depends on the ability of the athlete's own endurance, because by having good endurance the athlete is able to play great and bring out the best technique and ability without experiencing significant fatigue.

Maximal oxygen consumption $\left(\mathrm{VO}_{2} \mathrm{Max}\right)$ is the maximum volume of $\mathrm{O}_{2}$ that is processed by the human body during intensive activities. This volume of $\mathrm{O}_{2} \mathrm{max}$ is a level of body capability expressed in liters per minute or milliliter/minute $/ \mathrm{kg}$ body weight. Changes in $\mathrm{VO}_{2}$ max will occur due to the growth period, by measuring the maximum volume of oxygen we will know the amount of oxygen by the muscles to work, so that fitness is known. Fitness is useful for humans to carry out activities and show physical conditions without excessive fatigue (Utama et al., 2017). Fitness can be measured from the volume a person consumes oxygen at the maximum volume and capacity until fatigue occurs. The perceived fatigue of athletes will cause a decrease in concentration so that without good concentration on a game it is almost certain that failure will be accepted. Oxygen is our body's fuel. Oxygen is needed by the muscles in doing any heavy or light activity and the more oxygen the body absorbs shows the better the performance of the muscles at work so that the remaining substances that cause fatigue will be less. If the aerobic capacity is small, fatigue will come quickly". Aerobics itself really needs oxygen.

Physical ability factors in the skills of football athletes that are significant, but in weak levels are flexibility, explosive power, endurance, coordination, and anthropometry. Then, what produces a significant relationship in a strong degree is speed and agility. Meanwhile, strength and psychological are factors that have an insignificant relationship with very weak levels.

Football is a very complex sport in terms of its movement activities, so that almost all components of the physical condition are indirectly required to be improved by athletes in order to be able to do a better game of football.

\section{Conclusion and Recommendation}

The analysis descriptions indicate that the components of the physical condition are developed in support of the needs in the game of football is very broad. Research related to physical components is carried out for various techniques in football. However, the trend of physical components that are widely used is the physical component in general such as strength, flexibility, speed, endurance and anthopometric conditions especially the length of the arm and the length of the leg. 


\section{Acknowledgement}

The author would like to thank all those who contributed to this article, as well as other supporting components.

\section{References}

Abulyatama, F. U. (2018). = 1,76. Ternyata t. 194-204.

Adil, A. (2011). Kontribusi Kecepatan, Kelincahan, dan Koordinasi Mata Kaki Terhadap Kemampuan Menggiring Bola Pada Permainan Sepakbola PS. Aspura UNM. Ilara, 1(1), 70-77.

Anam, K. (2013). Pengembangan Latihan Ketepatan Tendangan Dalam Sepakbola Untuk Anak Kelompok Umur 13-14 Tahun. Media Ilmu Keolahragaan Indonesia, 3(2). https://doi.org/10.15294/miki.v3i2.4377

Anwar, S., Pendidikan, J., Kesehatan, J., \& Keolahragaan, F. I. (2013). Survei Teknik Dasar Dan Kondisi Fisik Pada Siswa Sekolah Sepak Bola (Ssb) Se Kabupaten Demak Tahun 2012. Active Journal of Physical Education, Sport, Health and Recreation, 2(9), 596-604. https://doi.org/10.15294/active.v2i9.1861

Azidman, L. (2017). Jurnal Ilmiah Pendidikan Jasmani, 1 (1) 2017. 1(1), 35-39.

Bompa, T., \& Buzzichelli, C. (2015). Periodization Training for Sports (Third Edit). Human Kinetics.

Fauzi, F. (2013). Tingkat keterampilan bermain sepakbola siswa ssb bina nusantara kabupaten klaten jurnal. Fakultas Ilmu Keolahragaan Yogyakarta, Universitas Negeri Yogyakarta.

Gamble, P. (2012). Training for Sports Speed and Agility (first). Routledge.

Guntoro, T. S., Muhammad, J., \& Qomarrullah, R. (2020). Faktor kemampuan fisik dan psikologis penunjang keterampilan atlet elit sepakbola Propinsi Papua Physical and psychological ability factors supporting the skills of Papua football elite athletes PEND AHULUAN Cabang olabraga (cabor) sepakbola merupakan ol. 6(2), 390-406.

Haff, G., \& Triplett, N. T. (2016). Essentials of Strength Training and Conditioning Fourth Edition (Fourth Edi). Human Kinetics.

Haxhiu, B., Gara, E., Durguti, Z., \& Gashi, F. (2016). Importance of physical therapists inclusion as members of football teams medical staff in Kosovo's super league and first league. Physiotherapy, 102, e201. https://doi.org/10.1016/j.physio.2016.10.245

Kekuatan, K., Tungkai, O., \& Dan, P. T. (2019). SUNGGUMINASA IV KABUPATEN GOWA Oleh: Aulia Ahmad Maulana Fakultas ilmu keolahragaan, universitas negeri makassar. 2019. 508(3).

Milanović, Z., Pantelić, S., Čović, N., Sporiš, G., Mohr, M., \& Krustrup, P. (2019). Broad-spectrum physical fitness benefits of recreational football: a systematic review and meta-analysis. British Journal of Sports Medicine, 53(15), 926-939. https://doi.org/10.1136/bjsports-2017-097885

Pérez-Gómez, J., Adsuar, J. C., Alcaraz, P. E., \& Carlos-Vivas, J. (2020). Physical exercises for preventing injuries among adult male football players: A systematic review. Journal of Sport and Health Science, 00. https://doi.org/10.1016/j.jshs.2020.11.003

Pratama, B. A. (2015). Kontribusi Kecepatan dan Kelentukan Terhadap Hasil Menggiring Bola. Jurnal SPORTIF: Jurnal Penelitian Pembelajaran, 1(1), 74. https://doi.org/10.29407/js_unpgri.v1i1.576

Putra, A. T., \& S, A. (2020). Kontribusi Kelentukan Dan Dayaledak Otot Tungkai Terhadap Heading Sepakbola. Jurnal Patriot, 2, 212-214.

Roberts, A. L., Taylor, H. A., Whittington, A. J., Zafonte, R. D., Speizer, F. E., Pascual-Leone, A., ... 
Weisskopf, M. G. (2020). Race in association with physical and mental health among former professional American-style football players: findings from the Football Players Health Study. Annals of Epidemiology, 51, 48-52.e2. https://doi.org/10.1016/j.annepidem.2020.07.013

Stoica, M., \& Blejan, C. (2013). Optimizing Physical Training through Adapted Specific Tests in High Performance Football. Procedia - Social and Behavioral Sciences, 93, 2136-2143. https://doi.org/10.1016/j.sbspro.2013.10.179

Syahda, I. A., Damayanti, I., \& Imanudin, I. (2016). Hubungan Kapasitas Vital Paru-Paru Dengan Daya Tahan Cardiorespiratory Pada Cabang Olahraga Sepak Bola. Jurnal Terapan Ilmu Keolahragaan, 1(1), 24. https://doi.org/10.17509/jtikor.v1i1.1549

Thompsett, B., Harland, A., \& Roberts, J. (2016). Investigating the Relationship between Physical Properties of a Football and Player Perceptions. Procedia Engineering, 147(0), 519-525. https://doi.org/10.1016/j.proeng.2016.06.231

Utama, M. W., Insanistyo, B., \& Syafrial, S. (2017). ANALISIS KEMAMPUAN TEKNIK DASAR BERMAIN SEPAKBOLA PADA PEMAIN USIA 16 TAHUN. KINESTETIK. https://doi.org/10.33369/jk.v1i2.3471

YUSUF DITYA, M. (2013). KONTRIBUSI PANJANG BETIS, PANJANG PAHA, DAN DAYA LEDAK TUNGKAI TERHADAP AKURASI MENENDANG PADA PEMAIN SEPAKBOLA(Studi pada Pemain Sepakbola BIMA AMORA U-16 Gresik). Jurnal Kesehatan Olabraga, 1(2). 